\title{
PENGARUH METODE BERMAIN DENGAN BAHAN BEKAS TERHADAP KEMAMPUAN BERHITUNG ANAK KELOMPOK B USIA 5-6 TAHUN
}

\author{
Ayu Ratna Pratiwi \\ Siti Fadjryana Fitroh \\ Dwi Nurhayati Adhani \\ Program Studi Pendidikan Guru Pendidikan Anak Usia Dini \\ Fakultas Ilmu Pendidikan Universitas Trunojoyo Madura \\ email: Fani.newhope@gmail.com
}

\begin{abstract}
Influence of Playing Methods With Used Materials Against Counting Capabilities of Group B Children Ages 5-6 Years. The purpose of the research is to know whether there is a significant influence of the method of playing with the used materials on the ability of counting children in group B (age 5-6 years) in Kindergarten Development Glagah Lamongan. This research uses quantitative approach by using experimental method with Preexperimental research design One-group pre-test post-test type. Number of samples of 15 children in group B Kindergarten Development Glagah Lamongan. Data collection techniques in this study through participant observation and documentation in the form of photos of activities and plans of daily learning. Demonstrate large data processing using Wilcoxon marked test data analysis. The result of data analysis obtained by $\mathrm{T}_{\text {count }}<\mathrm{T}_{\text {table }}(0<25)$ and Ha value received. Indicates that there was an increase in pretest of $27.5 \%$ to the time of posttest $43.49 \%$ Based on the data analysis there was a significant influence between the method of playing with used materials on the ability of counting children.
\end{abstract}

Keywords:Playing Methods, Used Materials, Counting Abilities, 5-6 Year Old Children.

\begin{abstract}
Abstrak: Pengaruh Metode Bermain Dengan Bahan Bekas Terhadap Kemampuan Berhitung Anak Kelompok B Usia 5-6 Tahun. Tujuan dari penelitian adalah untuk mengetahui adakah pengaruh yang signifikan dari metode bermain dengan bahan bekas terhadap kemampuan berhitung anak pada kelompok B (usia 5-6 tahun) di TK Pembangunan Glagah Lamongan. Penelitian ini menggunakan pendekatan kuantitatif dengan mengunakan metode eksperimen dengan desain penelitian Pre-eksperimental Desain jenis one-group pre-tes post-test. Jumlah sampel 15 anak pada kelompok B TK Pembangunan Glagah Lamongan. Teknik pengumpulan data dalam penelitian ini melalui observasi partisipan dan dokumentasi berupa foto-foto kegiatan dan rencana pelaksanaan pembelajaran harian. Menunjukkan besar pengolahan data menggunakan analisis data uji jenjang bertanda Wilcoxon. Hasil analisis data diperoleh nilai $\mathrm{T}_{\text {hitung }}<\mathrm{T}_{\text {tabel }}(0<25)$ dan $\mathrm{H}_{\mathrm{a}}$ diterima. Menunjukkan bahwa terjadi peningkatan saat pretest 27, $5 \%$ menjadi saat posttest $43,49 \%$ Berdasarkan analisis data tersebut terdapat pengaruh yang signifikan antara metode bermain dengan bahan bekas terhadap kemampuan berhitung anak.
\end{abstract}

Kata Kunci: Metode Bermain, Bahan Bekas, Kemampuan Berhitung, Anak Usia 5-6 Tahun.

Pendidikan merupakan suatu hal yang sangat penting untuk peradaban bangsa setiap negara di dunia ini. Karena pendidikan merupakan hal yang sangat memperhatikan setiap perubahanperubahan dengan jangka waktu yang panjang. Dalam hal ini pendidikan berperan memajukan generasi penerus bangsa melalui pembelajaran yang efektif dan mencakup semua aspek yang dikembangkan.

Undang-Undang Nomor 20 tahun 2003 tentang sistem pendidikan nasional menjelaskan bahwaPendidikan adalah suatu usaha sadar dan terencana untuk mewujudkan suasana belajar dan proses pembelajaran agar peserta didik secara aktif mengembangkan potensi dirinya untuk memiliki kekuatan spriritual keagamaan, pengendalian diri, kepribadian, kecerdasan, akhlak mulia, serta keterampilan yang diperlukan dirinya, masyarakat, bangsa dan negara.Pendidikan yang terencana dengan baik dapat di lihat dari sember daya manusia yakni pendidik dan peserta didik menghasilkan lulusan yang baik dengan tujuan pendidikan nasional. Tujuan pendidikan ialah menyediakan lingkungan yang memungkinkan peserta didik untuk mengembangkan bakat dan kemampuannya secara optimal, sehingga anak dapat mewujudkan dirinya dan berfungsi 
sepenuhnya, sesuai dengan kebutuhan pribadinya dan kebutuhan masyarakat. Sementara itu setiap anak mempunyai bakat dan kemampuan yang berbeda.

Pendidikan dilakukan seumur hidup sejak usia dini sampai akhir hayat. Arti penting mendidik anak sejak usia dini dilandasi dengan kesadaran bahwa masa kanak-kanak adalah masa keemasan (the golden age), karena pada usia ini anak dipandang memiliki tingkat perkembangan yang berbeda dengan anak usia di atasnya. Pada dasarnya anak usia dini belajar berdasarkan pengalaman belajar melalui mengamati, meniru dan bereksperimen yang berlangsung secara berulang-ulang yang dapat merangsang potensi multi intellegence anak di dalam kelas. Masa ini merupakan masa kritis bagi anak apabila tumbuh kembangnya tidak terpenuhi dengan baik, maka akan berpengaruh terhadap kemampuan perkembangan anak pada tahap selanjutnya. Pada usia dini stimulus yang sangat tepat diperlukan untuk membantu anak tumbuh kembang secara optimal.

Pentingnya pendidikan diberikan pada anak usia dini senada apa yang diungkapkan oleh "Maemunah Hasan mengungkapkan pendidikan anak usia dini adalah jenjang pendidikan sebelum jenjang pendidikan dasar yang merupakan suatu upaya pembinaan yang di tujukan bagi anak sejak lahir sampai dengan usia enam tahun yang di lakukan mulai pemberian rangsangan pendidikan guna membantu pertumbuhan dan perkembangan jasmani serta rohani agar anak memiliki kesiapan dalam memasuki pendidikan lebih lanjut yang di selenggarahkan pada jalur formal,non formal, dan informal" (Novan Ardy Wiyani, 2013: 19).

Disinilah tugas seorang guru anak usia dini sebelum melaksanakan program kegiatan belajar terlebih dahulu memperhatikan program kegiatan belajar anak usia dini. Sebagaimana program kegiatan belajar anak usia dini adalah untuk membantu meletakkan dasar ke arah perkembangan sikap, pengetahuan, keterampilan dan daya cipta yang diperlukan oleh anak didik dalam menyesuaikan diri dengan lingkungannya dan untuk pertumbuhan serta perkembangan selanjutnya. Guru dalam kegiatan pembelajaran untuk dapat menciptakan prakondisi yang menyenangkan bagi anak.

Adapun ruang lingkup program kegiatan belajar yang meliputi; pembentukan perilaku melalui pembiasaan dalam pengembangan moral Pancasila, agama, disiplin, perasaan/emosi, dan kemampuan bermasyarakat, serta pengembangan kemampuan dasar melalui kegiatan yang di persiapkan oleh guru melalui pengembangan kemampuan berbahasa, daya pikir, daya cipta, keterampilan dan jasmani. "Tujuan pendidikan anak usia dini yang ditarik dari tugas-tugas perkembangan yang harus diselesaikan tidak mungkin dilaksanakan sekaligus melainkan harus dijabarkan kedalam tugas-tugas yang kecil seperti tujuan pembelajaran, metode pembelajaran, startegi pembelajaran serta media pembelajaran yang diharapkan dapat memenuhi kebutuhan dalam perkembangan anak" (Suyono, 2012:1).

Pada kasus ekstrim, rendahnya tingkat kompetensi matematika prevalensi dari yang diperkirakan 5 sampai $7 \%$ di negara-negara industri seperti Amerika Serikat dan Inggris.konsep-konsep matematika bolic seperti pengetahuan dari urutan bilangan (misalnya, kata angka antara 1 dan 10) di 4-6 tahun. Bukti yang bertentangan tersebut menimbulkan pertanyaan tentang keandalan dan asalusul hubungan antara kedua sistem ini, dan jelas memerlukan kebutuhan untuk lebih lanjut melakukan percobaan (Justin W. Bonny And Stella F. Lourenco, 2012: 5).

Tiga domain keterampilan berhitung dan memeriksa tiga ratus sembilan puluh tiga anak berpartisipasi dalam penelitian ini $(51,7 \%$ perempuan, 55,7\% Putih, 33,8\% Afrika Amerika, dan 10,5\% lainnya). Hasil penelitian menunjukkan bahwa hubungan antara keterampilan berhitung resmi untuk di kembangkan. Hasil dari beberapa internasional besar Studi nasional pada matematika telah menunjukkan bahwa anakanak di Amerika menunjukkan Negara, seluruh sekolah mereka, tertinggal di belakang rekan-rekan internasional mereka di keterampilan matematika. Pembangunan berhitung, masing-masing mewakili sebuah domain berdeda. Selanjutnya, masingmasing domain ini diyakini menjadi pusat 
66 Jurnal PG-PAUD Trunojoyo : Jurnal Pendidikan dan Pembelajaran Anak Usia Dini, Volume 5, Nomor 1, April 2018, hal 64 - 74

pembangunan matematika anak-anak di prasekolah dan usia TK (David J. Purpura and Christopher J. Lonigan, 2013:7).

Berdasarkan hasil observasi di lapangan pada tanggal 17-19 Juni 2017 saat ini Guru pendidikan anak usia dini dituntut penyelenggara PAUD untuk mengajari anak berhitung sehingga anak dapat menguasai konsep dan keterampilan matematika yang merupakan penyebab kurangnya kemampuan berhitung pada anak yang masih kurang berkembang secara maksimal, hal ini di tandai oleh belum mampunya anak menghitung secara mundur serta acak. Belum mampu anak dalam menghitung benda menggunakan lambang bilangan, berhitung anak di TK tersebut dalam menyebut lambang bilangan untuk berhitung. Misalnya ketika guru menyuruh anak untuk menghitung sering tidak berurutan $(8,7,5,4,2)$ dan tidak mengenal angka misalnya ketika guru bertanya tentang angka diam saja.

Berdasarkan temuan di lapangan terdapat sekolah dasar dengan sengaja mengajukan persyaratan atau tes masuk dengan menggunakan kemampuan kognitif. Terutama tes membaca, menulis dan berhitung. Hal dilakukan pada saat penerimaan peserta didik baru di sekolah dasar. Akibatnya banyak pendidikan anak usia dini yang tidak lagi menjalankan fungsinya sebagai tempat bermain sambil belajar. Sehingga menjadikan anak merasa tertekan, dikerenakan waktu bermain anak semakin berkurang.

Permasalahan ini karena pendidik anak usia dini kurang menerapkan metode yang menarik bagi anak sehingga anak kurang tertarik dengan angka. Semua itu menjadi penyebab kurangnya minat anak pada berhitung. Mengajarkan sesuatu kepada anak dengan baik dan berhasil, perlu yang harus diperhatikan oleh guru adalah metode yang akan dilakukan, sehingga sasaran yang diharapkan dapat tercapai atau terlaksana dengan baik. metode merupakan fungsi alat untuk mencapai tujuan.

Berdasarkan hasil observasi salah satu metode yang sering digunakan oleh guru adalah metode drill yaitusebagai suatu cara mengajar dimana anak melaksanakan kegiatan-kegiatan latihan agar memiliki ketangkasan atau keterampilan yang lebih tinggi dari apa yang telah di pelajari oleh anak. Dalam metode drill ini, setiap latihan harus berbeda dengan latihan sebelumnya kerena situasi dan pengaruh latihan yang berbeda pula. Pemilihan metode drill dirasa guru paling mudah dan gampang untuk dipahami oleh anak tersebut tanpa mengetahui dampak dalam penggunaanya (Roestiyah NK, 2008:125).

Berdasarkan penelitian yang telah di lakukan di luar negeri Association for Psychological Science (APS) kemampuan berhitung menggunakan "Sistem Nomor Perkiraan (ANS) memberikan dasar kognitif untuk symbolic Kemampuan matematika, maka pelatihan yang meningkatkan ANS presisi harus mentransfer ke perbaikan dalam kemampuan simbolik-matematika. ANS juga memiliki praktek implikasi vertikal untuk intervensi yang bertujuan meningkatkan kemampuan matematika. Hasil ini menunjukkan bahwa peningkatan dalam ANS berdasarkan nonsymbolic, tugas pelatihan perkiraan aritmatika lebih dari beberapa sesi transfer ke baikan selektif kasih dalam kemampuan simbolik matematika (Joonkoo Park and Elizabeth M. Brannon, 2013:10).

Berdasarkan penelitian yang telah dilakukan oleh Sugiwati mengenai Metode Bermain Ular Tangga Untuk Meningkatkan Perkembangan Kognitif Kelompok A di TK. Ria Baruk Utara VIII/35 Rungkut-Surabaya. Bahwa dengan metode bermain ular tangga aktifitas guru mengalami peningkatan pembelajaran pada kelompok A di TK RIA, dengan metode bermain ular tangga dapat meningkatkan perkembangan kognitif kelompokA di TK RIA. Sehingga tujuan dari kegiatan pembelajaran dapat tercapai secara optimal (Sugiwati, 2013: 4).

Pembelajaran untuk anak usia dini adalah pembelajaran bermain sambil belajar yang berorientasi pada kebutuhan anak sehingga metode bermain sangat cocok diterapkan dalam pembelajaran untuk anak usia dini. Bermain lebih tampak menonjol daripada belajar. Kegiatan ini merupakan efek bawah sadar sehingga hasil dari bermain itu sangat kelihatan. Pada hasil anak bermain adalah anak memperoleh berbagai kemampuan, misalnya; kemampuan berkomunikasi, bahasa, bersosialisasi, pengaturan emosi, dan kemampuan berfikir 
logis metematis (Maria Montessori, 2015: 127).

Jenis-jenis permainan berhitung sangat beranekaragam salah satunya memanfaatkan bahan daur ulang/ barang bekas, misalnya; menyusun gelas aqua sambil dihitung, membuat bentuk gambar dari kardus kemudian digunakan untuk menghitung lambang bilangan, membuat bola dari remasan koran untuk memghitung mundur 1-20, banyak mana, berapa biji dan lain-lain. Karena permainan dari bahan daur ulang/bahan bekas sangat mudah di cari dan dengan harga yang sangat murah. Bermain adalah suatu kegiatan yang dilakukan dengan atau tanpa menggunakan alat yang menghasilkan pengertian atau memberikan informasi, memberikan rangsangan maupun mengembangkan imajinasi pada anak (Moeslichatoen, 2004: 2).

Menurut Bean limbah daur ulang atau bahan bekas merupakan salah satu alternatif di antara bahan-bahan limbah lainnya yang dapat dimanfaatkan dan dikreasikan kembali oleh pendidik menjadi media pembelajaran yang menarik untuk mengenalkan konsep matematika permulaan kepada anak usia 5-6 tahun. Sumber belajar bahan limbah bisa dimanfaatkan oleh guru tanpa mengeluarkan banyak uang dan sering dijumpai pada lingkungan sekitar yang dapat dikreasikan lagi sebagai sumber belajar yang menarik bagi anak dalam pembelajaran matematika permulaan sehingga kegiatan belajar mengajar dapat berjalan dengan lancar. Pendidik dapat mengenalkan konsep matematika permulaan kepada anak dengan menggunakan sumber belajar dengan bahan limbah (Hesti Hayuningtyas, 2014:8).

Hasil wawancara dengan guru pada tanggal 7 sampai 9 Juli 2017 di TK Pembangunan Glagah Lamongan menunjukkan hasil belajar pada aspek perkembangan kognitif khususnya dalam kemampuan berhitung belum tercapai secara maksimal. Tanda-tanda anak belum mampu berhitung salah satunya, bisa dilihat dalam perilaku anak waktu ditanya tentang berhitung anak hanya diam saja, atau ketika diminta menjawab anak menangis, saat anak di minta menghitung mundur 1-20 anak belum mampu sering ada angka yang terbalik, menghitung banyak benda lebih dari 10 , anak belum mampu membilang banyaknya benda. Hal ini dapat disimpulkan bahwa pembelajaran di TK Pembangunan Glagah Lamongan masih bersifat monoton. Metode dan media pembelajaran kurang variativ, sehingga atensi anak dalam mengikuti pembelajaran masih kurang. Anak masih cenderung melihat benda-benda yang tidak konkrit dalam pembelajaran.

Berdasarkan uraian di atas, peneliti tertarik untuk meneliti pengaruh metode bermain dengan bahan bekas terhadap kemampuan berhitung anak di pendidikan anak usia dini. Oleh sebab itu penelitian ini berjudul Pengaruh metode bermain dengan Bahan Bekas Terhadap Kemampuan Berhitung anak Pada Kelompok (usia 5-6 tahun)

\section{METODE}

Penelitian ini menggunakan metode eskperimen dengan desain Pre-Eksperimen (pre-exsperimental designs)Sugiyono (2014 : 3) yaitu penelitian yang belum merupakan eksperimen sungguh-sungguh, karena masih terdapat variabel luar yang ikut berpengaruh terhadap terbentuknya variabel dependen. Jenis penelitian yang digunakan oleh peneliti yaitu jenis One-Group Pretest-Posttest Design, dimana dalam penelitiannya terdapat pretest dan post test yang dilakukan untuk mengetahui dan membandingkan kemampuan kognitif sebelum dan sesudah diberi perlakuan.

Metode penelitian eksperimen dipilih oleh peneliti karena dalam penelitian peneliti akan mengukur pengaruh dari metode pemberian tugas terhadap kemampuan kognitif anak, sedangkan desain penelitian pre-eksperimen dipilih oleh peneliti karena dalam penelitian yang akan dilakukan oleh peneliti tidak menggunakan kelas kontrol selain itu dalam penelitian peneliti ini tidak menggunakan sampel random melainkan menggunakan sampel purposive yaitu sampel yang digunakan anak yang bermasalah.

Populasi dalam penelitian ini merupakan semua anak kelompok B TK Pembangunan Glagah Lamongan yang berjumlah 23 anak. Sedangkan sampel yang digunakan atau mewakili dalam penelitian ini yaitu 15 anak dalam kelompok B usia 5-6 tahun di TK Pembangunan Glagah Lamongan yang mana dalam pengambilan data anak sama-sama diberikan treatmen dan 
68 Jurnal PG-PAUD Trunojoyo : Jurnal Pendidikan dan Pembelajaran Anak Usia Dini, Volume 5, Nomor 1, April 2018, hal 64 - 74

dilakukan hasil observasi yaitu pretest dan posttest.

Teknik pengumpulan data yang digunakan dalam penelitian yaitu observasi dan dokumentasi.Kegiatan observasi peneliti menggunakan observasi participan. Penelitian ini peneliti menggunakan pedoman observasi dengan daftar cek/checklist yang berupa skala pengukuran skala dengan menggunakan 4 opsi yaitu belum berkembang, mulai berkembang, berkembang sesuai harapan, dan berkembang sangat baik.Teknik pengumpulan data selanjutnya yaitu dokumentasi. Teknik ini digunakan untuk mengumpulkan data berupa perangkat pembelajaran seperti hasil karya anak, RPPH, surat keterangan, dan foto-foto proses pembelajaran menggunakan metode pemberian tugas yang dilakukan pada kelompok B TK Pembangunan Glagah Lamongan.

Perhitungan analisis data dalam penelitian ini menggunakan uji normalitas dengan rumus liliefors. Sofiyan Siregar (2015:153) mengungkakan uji normalitas data dilakukan untuk mengetahui apakah data yang diperoleh dari populasi yang berdistribusi normal atau tidak. Hipotesis uji: $H o$ : Data berdistribusi tidak normal

$H a$ : Data berdistribusi normal $\alpha$ : Taraf nyata, dengan taraf signifikan $(\alpha)=$ $0,05(5 \%)$

Rumus yang digunakan dalam uji liliefors dapat dilakukan melalui beberapa langkah-langkah sebagai berikut:

1. Pilih nilai dari yang terkecil hingga terbesar

2. Mencari rata-rata, simpangan baku sampel kemudian tentukan nilai bakunya dengan menggunakan rumus $Z=\frac{x_{i}-\bar{x}}{s}$

3. Hitung peluang $F(z i)=P(z i)$

4. Hitung proporsi yang lebih kecil atau sama dengan $z i \geq S(z i)$

5. Hitung $|F(z i)-S(z i)|$

6. Statistik uji dengan $\alpha$ tertentu tentukan titik kritis L dan Kriteria uji jika $L o=L_{h \text { itung }} \leq L_{\text {tabel }}$ (Terima Ho)

$$
L o=L_{\text {hitung }}>L_{\text {tabel }}(\text { Tolak Ho). }
$$

\section{HASIL DAN PEMBAHASAN}

Hasil penelitian ini menjelaskan secara rinci mengenai pengaruh metode Bermain dengan bahan bekas terhadap kemampuan berhitung kelompok B di TK Pembangunan Glagah Lamongan. sebelum adanya perlakuan dan sesudah diberi perlakuan. Adapun hasil penelitian sebelum perlakuan (pretest) ini dapat disajikan dalam tabel sebagai berikut:

Tabel 1. Data Kemampuan Berhitung Anak Sebelum Perlakuan

\begin{tabular}{|c|c|c|c|c|c|c|c|c|c|c|c|c|c|c|c|}
\hline \multirow{3}{*}{$\begin{array}{l}\text { Siswa } \\
\text { AGR }\end{array}$} & \multicolumn{6}{|c|}{ Indikator Pengamat 1} & \multicolumn{6}{|c|}{ Indikator Pengamat 2} & \multirow{3}{*}{\begin{tabular}{|l|}
$\sum$ \\
17
\end{tabular}} & \multirow{3}{*}{1,4} & \multirow{2}{*}{$\begin{array}{l}\text { Kri } \\
\text { te } \\
\text { ria } \\
\end{array}$} \\
\hline & \multicolumn{4}{|l|}{$\mathrm{A}$} & \multicolumn{2}{|l|}{ B } & \multicolumn{4}{|l|}{$\mathrm{A}$} & \multicolumn{2}{|l|}{ B } & & & \\
\hline & 1 & 2 & 1 & 2 & 2 & 1 & 1 & 1 & 1 & 2 & 2 & 1 & & & $\mathrm{BB}$ \\
\hline ASDS & 2 & 3 & 3 & 2 & 2 & 1 & 4 & 1 & 2 & 3 & 2 & 1 & 26 & 2,2 & MB \\
\hline ASM & 2 & 3 & 2 & 1 & 2 & 2 & 3 & 4 & 2 & 4 & 1 & 1 & 27 & 2,3 & MB \\
\hline FR & 2 & 2 & 2 & 3 & 1 & 2 & 3 & 1 & 1 & 3 & 2 & 1 & 23 & 1,9 & MB \\
\hline OYW & 2 & 3 & 1 & 3 & 2 & 1 & 2 & 2 & 2 & 2 & 2 & 2 & 24 & 2,0 & MB \\
\hline MYH & 2 & 2 & 2 & 2 & 2 & 2 & 2 & 2 & 1 & 3 & 2 & 1 & 23 & 1,9 & MB \\
\hline HWS & 2 & 2 & 3 & 4 & 1 & 2 & 2 & 1 & 2 & 3 & 1 & 2 & 25 & 2,1 & $\mathrm{MB}$ \\
\hline MQF & 2 & 2 & 2 & 4 & 2 & 1 & 3 & 1 & 2 & 4 & 1 & 2 & 26 & 2,2 & MB \\
\hline MAM & 1 & 2 & 3 & 2 & 1 & 2 & 2 & 2 & 2 & 2 & 1 & 1 & 21 & 1,8 & $\mathrm{MB}$ \\
\hline RPDR & 2 & 1 & 1 & 2 & 1 & 2 & 1 & 2 & 1 & 3 & 2 & 1 & 20 & 1,7 & BB \\
\hline AEZS & 1 & 2 & 2 & 3 & 2 & 1 & 3 & 2 & 2 & 3 & 1 & 2 & 24 & 2,0 & MB \\
\hline ASA & 1 & 2 & 1 & 1 & 2 & 1 & 2 & 1 & 1 & 2 & 1 & 1 & 16 & 1,3 & $\mathrm{BB}$ \\
\hline MBAF & 2 & 2 & 2 & 3 & 1 & 2 & 1 & 1 & 1 & 1 & 2 & 1 & 19 & 1,6 & $\mathrm{BB}$ \\
\hline NVAAF & 1 & 2 & 2 & 3 & 1 & 2 & 1 & 2 & 2 & 3 & 1 & 2 & 22 & 1,8 & MB \\
\hline MRSW & 1 & 2 & 1 & 2 & 1 & 2 & 1 & 1 & 1 & 1 & 1 & 1 & 15 & 1.3 & BB \\
\hline
\end{tabular}


Berdasarkan tabel 1 diatas adalah tabel data nilai sebelum perlakuan kemampuan berhitung, bentuk dan ukuran pada anak kelompok B usia 5-6 tahun, pada penelitian ini menggunakan sampel purposive karena saat pengambilan sampel mempertimbangkan hasil tertentu. Adapun di kelompok B usia 5-6 tahun TK Pembangunan Glagah Lamongan yang termasuk dalam sampel purposive terdiri dari 15 anak. Data yang telah terpapar pada tabel diatas merupakan nilai dari jumlah indikator yang telah ditentukan oleh peneliti, jumlah yang ditentukan peneliti yaitu 3 indikator 6 pernyataan diantaranya yaitu Anak mampu menyebutkan dengan lambang bilangan 1-20 dengan tepat, Anak mampu mencocokkan bilangan dengan lambang bilangan 1-20 secara tepat, Anak mampu menunjukkan bilangan yang jumlahnya (lebih banyak, lebih sedikit, sama) 1-20 secara tepat, Anak mampu mengurutkan lambang bilangan 1-20 dengan benda secara tepat, Anak mampu mengelompokkan jumlah benda sejenis 1-20 secara tepat, Anak mampu menyebutkan jumlah benda dengan cara menghitung 1-20 secara tepat.

Berdasarkan hasil dari tabel diatasbahwa hasil nilai dari kemampuan berhitung sebelum perlakuan (treatment) metode bermain dengan bahan bekas tugas secara kumulatif terdapat 5anak yang tergolong dalam kriteria belum berkembang (BB) dan 10 anak yang tergolong dalam kriteria mulai berkembang (MB).

Selanjutnya yaitu pemaparan hasil penelitian sesudah perlakuan (postest) sebagai berikut :

Tabel 2. Data Kemampuan Berhitung Sesudah Perlakuan

\begin{tabular}{|c|c|c|c|c|c|c|c|c|c|c|c|c|c|c|c|}
\hline \multirow[t]{2}{*}{ Siswa } & \multicolumn{6}{|c|}{ Indikator Pengamat 1} & \multicolumn{6}{|c|}{ Indikator Pengamat 2} & \multirow[t]{2}{*}{$\sum$} & \multirow[t]{2}{*}{$\bar{X}$} & \multirow{2}{*}{$\begin{array}{l}\text { Kri } \\
\text { te } \\
\text { ria }\end{array}$} \\
\hline & \multicolumn{4}{|c|}{ A } & \multicolumn{2}{|c|}{$\mathrm{B}$} & \multicolumn{4}{|c|}{ A } & \multicolumn{2}{|c|}{ B } & & & \\
\hline AGR & 3 & 2 & 2 & 2 & 3 & 1 & 3 & 2 & 2 & 1 & 2 & 1 & 24 & 2,00 & MB \\
\hline ASDS & 4 & 4 & 4 & 4 & 4 & 3 & 4 & 4 & 3 & 4 & 4 & 3 & 45 & 3,75 & BSB \\
\hline ASM & 4 & 3 & 4 & 4 & 4 & 3 & 4 & 3 & 3 & 4 & 4 & 3 & 43 & 3,58 & BSB \\
\hline FR & 4 & 3 & 3 & 3 & 4 & 2 & 3 & 3 & 2 & 3 & 4 & 3 & 37 & 3,08 & BSH \\
\hline OYW & 3 & 3 & 3 & 3 & 3 & 2 & 3 & 2 & 1 & 4 & 3 & 3 & 33 & 2,75 & BSH \\
\hline MYH & 3 & 2 & 4 & 3 & 3 & 3 & 3 & 3 & 3 & 4 & 3 & 3 & 37 & 3,08 & BSH \\
\hline HWS & 4 & 3 & 3 & 4 & 3 & 4 & 3 & 4 & 3 & 4 & 3 & 3 & 41 & 3,42 & BSB \\
\hline MQF & 4 & 3 & 4 & 4 & 4 & 4 & 4 & 4 & 4 & 4 & 3 & 3 & 45 & 3,75 & BSB \\
\hline MAM & 4 & 2 & 3 & 2 & 3 & 3 & 4 & 4 & 3 & 2 & 2 & 2 & 34 & 2,83 & BSB \\
\hline RPDR & 4 & 3 & 3 & 2 & 2 & 2 & 3 & 2 & 3 & 3 & 3 & 2 & 32 & 2,67 & $\mathrm{BSH}$ \\
\hline AEZS & 4 & 3 & 3 & 3 & 3 & 2 & 3 & 3 & 3 & 4 & 3 & 2 & 36 & 3,00 & BSH \\
\hline ASA & 3 & 3 & 2 & 4 & 3 & 2 & 3 & 4 & 4 & 3 & 3 & 3 & 37 & 3,08 & BSH \\
\hline MBAF & 1 & 2 & 2 & 3 & 3 & 2 & 2 & 2 & 2 & 3 & 2 & 1 & 25 & 2,08 & MB \\
\hline NVAAF & 2 & 2 & 2 & 3 & 3 & 2 & 1 & 3 & 1 & 3 & 2 & 2 & 26 & 2,17 & $\mathrm{MB}$ \\
\hline MRSW & 2 & 2 & 2 & 3 & 3 & 2 & 3 & 2 & 2 & 2 & 2 & 2 & 27 & 2,25 & MB \\
\hline
\end{tabular}

Berdasarkan tabel 2 diketahui bahwa hasil nilai dari kemampuan berhitung pada anak yang sudah diberikan perlakuan (treatment) dengan metode bermain dengan bahan bekassecara kumulatif terdapat 4 anak yang masuk dalam anak masuk dalam katagori mulai berkembang (MB), 6kategori berkembang sesuai harapan (BSH), dan terdapat 5 anak yang masuk dalam kategori berkembang sangat baik (BSB).

Berdasarkan tabel sebelum dan sesudah perlakuan dapat dilihat bahwa sampel yang dipilih oleh peneliti mengalami peningkatan pada saat sesudah perlakuan (treatment) dengan menggunakan metode bermain dengan bahan bekas. Selain itu, berdasarkan hasil tabel diatas juga dapat digunakan untuk menyusun perhitungan dalam menguji kebenaran hipotesis mengenai "Pengaruh Metode Bermain dengan Bahan Bekas Terhadap Kemampuan Berhitung Kelompok B Usia 5-6 Tahun di TK Pembangunan Glagah Lamongan".

Selain dari hasil perbandingan hasil data diatas, hal tersebut dapat dibuktikan dari perhitungan data pada penelitian ini dengan menggunakan uji jenjang bertanda Wilcoxon menunjukkan bahwa, nilai yang diperoleh Thitung < Ttabel $(0<25)$. Hal ini menunjukan bahwa nilai 0 jauh dibawah 25 . Nilai kriteria keputusan pada jenjang bertanda Wilcoxon yang telah terpapar diatas dapat disimpulkan bahwa Ha diterima, yang artinya ada pengaruh yang signifikan antara penerapan 
70 Jurnal PG-PAUD Trunojoyo : Jurnal Pendidikan dan Pembelajaran Anak Usia Dini, Volume 5, Nomor 1, April 2018, hal 64 - 74

bermain terhadap kemampuan berhitung anak usia 5-6 tahun di TK Pembangunan Glagah Lamongan.

Metode bermain anak dapat melakukan kegiatan yang dapat mengembangkan kemampuannya mengingat bahwa anak usia dini adalah kelompok anak yang berada dalam proses pertumbuhan dan perkembangan yang bersifat unik. Yaitu, pola pertumbuhan dan perkembangan (koordinasi motorik halus dan kasar), intelegensi (daya pikir, daya cipta, kecerdasan emosi, dan kecerdasan spiritual), sosial emosional (sikap dan perilaku serta agama), bahasa, dan komunikasi yang khusus sesuai dengan tingkat pertumbuhan dan perkembangan anak (Muhammad fadlillah, 2012:19).

Suatu treatment atau perlakuan yang telah dilaksanakan yaitu dengan menggunakan metode bermain untuk mengajarkan kemampuan berhitung pada anak usia 5-6 tahun di TK Pembangunan merupakan suatu bentuk upaya untuk merubah perilaku anak dari yang belum bisa berhitung menjadi mampu berhitung. Pemilihan metode yang digunakan disesuaikan dengan metode yang telah ditetapkan dalam Peratuan Menteri Pendidikan dan Kebudayaan Republik Indonesia Nomor 146 Tahun 2014 tentang Kurikulum 2013 Bab III yang menyebutkan bahwa salah satu metode pembelajaran yang diterapkan di Taman Kanak-kanak adalah metode bermain.

Adapun langkah-langkah yang diambil peneliti sebelum pelaksanaan yaitu peneliti mengambil langkah pertama yaitu persiapan, pada langkah ini peneliti merencanakan kegiatan bermain, tujuan dari kegiatan bermain, peneliti berunding dengan para dewan guru TK Pembangunan Desa Glagah Pasar Kecamatan Glagah Kabupaten Lamongan, dan mempertimbangkan kegiatan bermain yang menggunakan bahan bekas dapat menumbuhkan perkembangan kognitif anak. Saat musyawarah ada salah satu guru memberikan pendapatnya, beliau berpendapat pada treatment I bahwa kegiatan bermain yang nantinya dilakukan anak dalam kelas yang luas tanpa ada meja dan kursi yaitu terlebih dahulu anak diminta menyebutakan bilangan 1-20.
Selanjutnya oleh guru untuk menstimulus kemampuan anak pada treatment II dalam menghitung banyak benda dan mengurutkan lambang bilangan dengan rangkaian kegiatan yaitu menyebutkan lambang bilangan dengan angka bekas kalender, menghitung jumlah benik dicocokkan dengan lambang bilangannya, membedahkan potongan kardus mana yang lebih banyak, lebih sedikit dan sama, mengurutkan botol bekas bertempelkan bilangan yang di mualai dari angka 1 sampai 20, mengelompokkan bungkus permen warna warni, dan menghitung banyak potongan kardus di kotak 1 dan kotak 2 kemudian di gabung di kotak 3 yang di lakukan anak sebagai kegiatan lomba dan guru.

Langkah kedua yaitu menetapkan rancangan bahan dan alat yang diperlukan dalam kegiatan bermain sesuai dengan rancangan tujuan dan tema yang ditetapkan maka dapat ditetapkan rancangan bahan dan alat yang dapat disediakan guru sesuai tema dan kegiatan yang sudah dirancang oleh guru. Peneliti bersama guru berunding untuk mempersiapkan alat dan bahan yang digunakan selama proses kegiatan belajar mengajar menggunakan metode bermain. Alat dan bahan yang perlu disiapkan yaitu angaka pada kalender, sedotan bekas es, botol bekas, potongan kardus di bentuk lingkaran, segitiga, kotak, benik bekas baju, wadah kue, botol teh, lem, kardus sepatu, bungkus permen.

Langkah ketiga yaitu pelaksanaan, sebelum permainan lomba di mulai anakanak dibariskan terlebih dahulu dan menjelaskan bahwa kita akan melakukan kegiatan lomba, guru sedikit menstimulus anak bahwa permainan ini sangat menyenangkan dan dapat memanfaatkan bahan-bahan bekas yang terbuang. Setelah menjelaskan tujuan bermain guru menjelaskan tata tertib pelaksanaan metode bermain. Usai diarahkan anak-anak diajak untuk membaca basmallah sebelum kegiatan lomba dlaksanakan. Pada pelaksanakan metode pembelajaran bermain peneliti didampingi oleh 1 guru, dan membimbing dan mengatur beberapa abak yang kurang mematuhi tata tertib yang telah ditetapkan dalam permainan. 
Saat permainan di mulai anak di sebutkan namanya untuk bermain dan yang lainnya mengantri secara bergantian, dan peneliti melakukan penilaian pada aspek konsep bilangan dan lambang bilangan yang telah tersusun di lembar observasi. Berikut adalah nilai dari hasil posttest Adapun indikator yang diteliti yaitu membilang dengan benda 1 sampai 20 , membuat urutan bilangan 1-20 dengan benda, dan menghitung banyak benda 1-20.

Hasil sesudah perlakukan (posttest) diketahui hasil dari pengamat 1 dan pengamat 2 kemudian dihitung nilai rata-rata sehingga peneliti menemukan hasil nilai setiap anak menunjukkan bahwa kemampuan berhitung anak kelompok B di TK Pembangunan Glagah Lamongan yang secara keseluruhan 4 anak mendapatkan nilai mulai berkembang (MB) 6 anak mendapatkan nilai dengan kriteria berkembang sesuai harapan (BSH), 5 anak mendapatkan nilai dengan kriteria berkembang sangat baik (BSB). Hal tersebut dapat dibuktikan dengan melihat lampiran 5.

Berdasarkan dari hasil nilai yang telah di paparkan diatas dapat diuraikan dari masingmasing anak antara lain anak AGR mendapatkan nilai 2,00 dengan kriteria $\mathrm{MB}$, anak ASDS mendapatkan nilai 3,75 dengan kriteria BSB, anak ASM mendapatkan nilai 3,58 dengan kriteria BSB, anak FR mendapatkan nilai 3,08 dengan kriteria $\mathrm{BSH}$, anak OYW mendapatkan nilai 2,75 dengan kriteria $\mathrm{BSH}$, anak MYH mendapatkan nilai 3,08 dengan kriteria BSH, anak HWS mendapatkan nilai 3,42 dengan kriteria BSB, anak MQF mendapatkan nilai 3,75 dengan kriteria BSB, anak MAM mendapatkan nilai 2,83 dengan kriteria $\mathrm{BSH}$, anak RPDR mendapatkan nilai 2,67 dengan kriteria $\mathrm{BSH}$, anak AEZS mendapatkan nilai 3,00 dengan kriteria $\mathrm{BSH}$, anak ASA mendapatkan nilai 3,08 dengan kriteria BSH, anak MBAF mendapatkan nilai2,08 dengan kriteria MB,anak NWAAF mendapatkan nilai 2,17 dengan kriteria MB, anak MRSW mendapatkan nilai 2,25 dengan kriteria MB.

Mengajarkan anak usia dini pada pembelajaran disekolah merupakan suatu tugas guru yang harus menciptakan suasana belajar seraya bermain, sehingga anak merasa tidak monoton dan pembelajaran mudah dipahami oleh anak. Salah satu model pembelajan yang tepat untuk anak usia dini yaitu metode pembelajaran bermain menurut Departemen Pendidikan Nasional merupakan salah satu motode pembelajaran pada program anak usia dini yang berpusat pada anak. Dalam metode ini, ruangan kelas disetting di jadikan sebagai kegiatan bermain. Berdasarkan penggunaan metode bermain dapat diketahui pada kemampuan akhir sesudah perlakuan (posttest) yang awalnya belum berkembang (BB) mengalami sebuah peningkatan mulai berkembang (MB) dan anak yang awalnya berkembang sesuai harapan (BSH) mengalami sebuah peningkatan menjadi berkembang sangat baik (BSB).

Metode pembelajaran bermain bahan bekas pada anak usia dini dapat mengembangkan berbagai aspek perkembangan yang sesuai dengan pertumbuhan yang dimiliki oleh individu anak. Berikut adalah beberapa macammacam perkembangan menurut berbagai pendapat, namun dalam pelaksanaan penelitian ini tidak semua perkembangan tersebut muncul. Adapun macam-macam perkembangan yang dijumpai peneliti akan dibahas dan dianalisis sesuai teori dan keadaan lapangan saat penelitian.

Berdasarkan macam perkembangan yang pertama ditemui peneliti saat pelaksanaan pembelajaran bermain yaitu perkembangan fisik-motorik, dalam proses belajar mengajar dapat dijumpai fisik motorik pada anak baik motorik halus maupun motorik kasar. Motorik halus muncul pada saat anak menghitung banyaknya potongan kertas dari kotak satu dan kotak kedua kemudian di pindahkan ke kotak tiga, sedangkan pada motorik kasar yang muncul ketika anak berjalan mengambil potongan kardus yang di hitung. Hal ini senada dengan Parten bahwa bermain adalah salah satu alat utama yang menjadi latihan jasmani untuk pertumbuhannya Samiawan Conny (2008:20).

Perkembangan kedua yang muncul pada saat belajar yaitu perkembangan emosi. Berbagai pendapat menyatakan perkembangan emosi adalah suatu perasaan yang memiliki oleh seorang anak, baik perasaan senang maupun sedih. Emosi ini mulai berkembang semenjak anak lahir kedunia. Meskipun ada anggapan bahwa 
sejak dalam kandungan seseorang sudah dapat merasakan sesuatu. Perkembangan emosi pada diri seorang anak akan muncul manakala anak mengalami interaksi dengan lingkungannya. Pada anak usia dini, ungkapan perasaan ini ditunjukkan melalui berbagai pespons yang dapat dilakukannya Samiawan Conny (2008:20).Hal ini terbukti pada proses belajar pemberian perlakuan (treatmen) anak antusias dan menunjukkan perasaan senang melakukan bermain karena guru membawa benda konkret dan menyediakan alat dan bahan untuk bermain menggunakan bahan bekas.

Perkembangan yang ketiga yang muncul pada saat belajar yaitu perkembangan bahasa. Hal ini terbukti pada proses belajar pemberian perlakuan (treatmen) anak dapat menjawab dan menghitung dengan benar dan tepat. Hal ini senada dengan Eheart dan Leavitt mengatakan bahwa pembelajaran dapat mengembangkan berbagai potensi pada anak, tidak saja pada potensi fisik tetapi pada perkembangan bahasa pada akhirnya prestasi akademik. Wolfgang berpendapat bahwa terdapat sejumlah nilai-nilai dalam bermain ( the value of play) dalam Samiawan Conny (2008:20).

Perkembangan keempat yang muncul pada saat belajar yaitu perkembangan kognitif. piaget mengungkapkan bahwa asimilasi merupakan proses dimana stimulus baru dari lingkungan diintegrasikan pada pengetahuan yang telah ada pada diri anak. proses ini dapat diartikan sebagai suatu objek atau ide baru ditafsirkan sehubungan dengan gagasan atau teori yang diperoleh anak (Muhammad Fadilah, 2012:42).

Pengertian ini memberikan suatu penjelasan dan pemahaman bahwa kemampuan kongnisi seorang anak itu berkembang melalui proses rangsangan yang diperolehnya dalam kehidupan sehai-har. Selanjutnya rangsanganrangsangan tersebut diterima dan dan itafsirkan melalui daya fikirnya yang kemudian diwujudkan dengan perbuatan. Hal ini terbukti pada saat treatmen pada indikator menghitung banyak benda pada pernyataan pada pernyataan anak mampu menyebutkan jumlah benda dengan cara berhitung, pada kotak satu terdapat potongan lima kemudian di kotak dua ada potongan lima di gabungkan ke kotak tiga dengan hasil sepuluh, anak dapat menghitung benda dengan tepat dan benar kemudian anak menerapkan dengan menggunkan jari sendiri bahwa $5+5=10$.

Hal ini terbukti bahwa metode pembelajaran bermain dapat menstimulus perkembangan kognitif pada aspek konsep bilangan dan lambang bilangan anak. selain dapat meningkatkan perkembangan kognitif motode bermain juga dapat meningkatkan kemampuan fisik motorik, sosial emosional, bahasa dan lain-lain. Hal ini senada dengan paparan yang telah dipaparkan oleh Hetherington \& Parke di atas, Dworetzky mengemukakan bahwa fungsi bermain dan interaksi dalam permainan mempunyai peran penting bagi perkembangan kognitif dan sosial anak. Bermain juga merupakan tunutan dan kebutuhan esensial bagi anak usia dini. Melalui bermain anak akan dapat memuaskan tuntutan dan kebutuhan perkembangan dimensi motorik, kognitif, kreativitas, bahasa emosi, sosial dan nilai sikap hidup dalam Masito (2008: 9.5).

Metode pembelajaran bermain dengan bahan bekas sama halnya dengan metode pembelajaran lainnya yang media dari bahan bekas mempunyai titik kelemahan, adapun titik kelemahan dari bahan bekas yaitu bahan gampang rusak dan tidak tahan lama. Berdasarkan dari paparan mengenai kelemahan dari metode bermain jika dipadukan dengan kondisi lapangan memang ada beberapa kelemahan muncul saat metode bermain diterapkan sebagai treatment. Ada beberapa kelemahan metode bermain dengan munggunkan bahan bekas yang memang menghambat berlangsungnya kegiatan lomba berhitung diantaranya yaitu saat anak melakukan kegiatan bermain lomba banyak media yang terbuat dari potongan kardus rusak karena sering di buat main anak-anak, botol yang sudah di urutkan di tendang oleh anak sampai kertas angkanya lepas, hal tersebut sangat menganggu proses kegiatan berlangsung.

Guru kesulitan dalam mengatur anak dan kesulitan dalam mengkondisikan kegiatan belajar mengajar menggunakan metode bermain dengan bahan bekas. Sehingga dalam kegiatan menggunakan metode bermain dengan bahan bekas sangat membutuhkan energi yang cukup banyak. Adapun kelemahan yang tidak muncul saat 
menggunakan media bahan bekas dalam proses pembelajaran metode bermain ini diterapkan sebagai treatment diantaranya yaitu dalam penelitian peneliti tidak menemui suatu kendala yang berkenaan dengan bahaya bahan bekas atau bahannya kotor pada saat pelaksanaan karena sebelum kegiatan lomba diadakan guru bersama dengan peneliti membersikan dan mencuci terlebih dahalu barang-barang yang akan digunakan dan karena persiapan sudah matang akhirnya penerapan metode pembelajaran bermain menggunakan bahan bekas berjalan dengan lancar dan kegiatan inti tidak terabaikan.

Mengingat bahwa pentingnya mengajarkan tentang berhitung pada anak usia dini dalam kegiatan sehari-hari. Akhirakhir ini pembelajaran berhitung yang diberikan pada anak usia dini menjadi perdebatan, kapan waktu yang tepat untuk mengenalkan berhitung pada anak. hanya saja saat penyelenggaraan pembelajaran berhitung harus di selengi bermain dan dihadapkan dengan dunia nyata, karena pada dasarnya karakteristik anak salah satunya yaitu anak lebih bergairah belajar dari pengalaman yang mereka dapat. Hal ini senada dengan teori yang dikemukakan oleh Maria Montessori defisien di London salah satu cara pertama untuk mengenalkan berhitung anak yang pertama di gunakan adalah menghitung dengan uang. Permainan bertukar uang merupakan salah satu permainan berhitung yang sangat menarik yang dapat mempertahankan perhatian dari anak. saya menyajikan satu,dua, dan empat keping dan anak-anak, dengan dengan cara ini berhitung hingga dua puluh Maria Montessori (2015:359).

Teori tersebut juga dapat dibuktikan kebenarannya dengan hasil pretests. Anak hanya dihadapkan dengan LKA atau lembar kerja anak dan menggunakan sistem belajar seperti latihan-latihan soal memperoleh nilai yang rendah, dan pada saat posttest dengan menerapkan metode bermain dengan bahan bekas (memperdalam pengalaman seharihari), memperoleh nilai rata-rata jauh lebih tinggi dibandingkan pretest, hal ini dikarenakan anak mengalami gairah rasa ingin tahu yang besar saat dihadapkan dengan pengalaman seharihari yang pernah anak lakukan. Dan saat pembelajaran berhitung diberikan pada anak tidak semuanya berjalan dengan lancar, pastinya ada hambatan-hambatan yang telah ditemui oleh peneliti saat penerapan metode bermain dengan bahan bekas untuk menstimulus perkembangan kognitif dalam hal konsep bilangan dan lambang bilangan, dimana anak saling berebutan untuk lebih dulu bermain tanpa harus mengantri lebih dulu.

Selain dari memadukan hasil dari pretest dan posttest dengan teori-teori yang mendukung, pada penelitian ini juga dilakukan perhitungan uji hipotesis, adapun hasil uji hipotesis tersebut menggunakan uji jenjang bertanda wilcoxon yang memperoleh nilai $\mathrm{T}_{\text {hitung }} 0$ dan $\mathrm{T}_{\text {tabel }} 25$, maka Thitung jauh lebih kecil dibanding dengan $\mathrm{T}_{\text {tabel }}(0<25)$, maka, jika $\mathrm{T}_{\text {hitung }}<\mathrm{T}_{\text {tabel }} \mathrm{H}_{\mathrm{a}}$ diterima yang artinya ada pengaruh signifikan antara penerapan metode bermain dengan bahan bekas terhadap kemampuan berhitung anak pada kelompok B (usia 5-6 tahun) di TK Pembangunan Glagah Lamongan.

Berdasarkan hasil penelitian yang dipadukan dengan teori-teori yang mendukung, dan berdasarkan perhitungan uji hipotesis yang dilakukan dengan uji jenjang bertanda wilcoxon yang hasilnya telah terpapar diatas, maka dapat menjawab rumusan masalah bahwa ada pengaruh metode bermain dengan bahan bekas terhadap kemampuan berhitung anak pada kelompok B (usia 5-6 tahun) di TK Pembangunan Glagah Lamongan.

\section{SIMPULAN}

Berdasarkan hasil penelitian dapat disimpulkan bahwa terdapat pengaruh yang signifikan antara metode bermain dengan bahan bekas terhadap kemampuan berhitung anak kelompok B usia (5-6 tahun) TK Pembangunan Glagah Lamongan. Hal tersebut terbukti dari hasil perhitungan uji jenjang bertanda Wilcoxon memperoleh nilai $\mathrm{T}_{\text {hitung }}<\mathrm{T}_{\text {tabel }}(0<25)$, maka $\mathrm{H}_{\mathrm{a}}$ diterima.

\section{DAFTAR PUSTAKA}

Bonny, J. W. dan Lourenco, S. F. (2012). The Approximate Number System And Its Relation To Early Math Achievement: Evidence From The Preschool Years 
74 Jurnal PG-PAUD Trunojoyo : Jurnal Pendidikan dan Pembelajaran Anak Usia Dini, Volume 5, Nomor 1, April 2018, hal 64 - 74

David, J. P. dan Lonigan, C. J., (2013). Informal Numeracy Skills: The Structure And Relations Among Numbering, Relations, And Arithmetic Operations In Preschool. Vol. 50 No.1

Fadillah, M. (2012). Desain Pembelajaran PAUD. Yogyakarta: Ar-Ruzz Media.

Kualitatif, dan $R \& D$. Bandung: Alfabeta.

Suyono. (2012). Belajar Dan Pembelajaran. Bandung: Remaja Rordakarya.

Wiyani, A. N. (2013). Bina Karakter Anak Usia Dini. Jogjakarta: AR-RUZZ MEDIA.

Hesti Hayuningtyas, 2014. Pemanfaatan Sumber Belajar Dengan Limbah Kardus untuk MengembangkanKonsep Matematika Permulaan Anak Usia 5-6 Tahun (Studi Eksperimen Di Tk Taman Indria Semarang). Vol 3 No.1

Masitoh. dkk. (2008). Strategi Pembelajaran TK. Jakarta: Universitas Terbuka.

Moeslichatoen. (2004). Metode Pengajaran di Taman Kanak-Kanak Jakarta: PT. Rineka Cipta.

Montessori, M. (2015). Metode Montessori panduan wajib untuk guru dan orangtua didik PAUD Yogyakarta: Pustaka Belajar.

Park, J. dan Brannon, E. M.. (2013). Training the Approximate Number System Improves Math Proficiency. Vol. 24 No, 10 Journal Homepage: www.elsevier.com/Locate/Jecp

Roestiyah. (2008). Strategi Belajar Mengajar. Jakarta: Bina Aksara.

Semiawan, C. (2008). Belajar dan pembelajaran prasekolah dan sekolah dasar. Indonesia: PT macanan Jaya Cemerlang.

Siregar, S. (2015). Statistika Parametrik Untuk Penelitian Kuantitatif. Jakarta: PT BumiAksara.

Sugiwati. (2013). Metode Bermain Ular Tangga Untuk Meningkatkan Perkembangan Kognitif Kelompok A di TK. Ria Baruk Utara VIII/35 Rungkut-Surabaya. Vo 2 No 1

Sugiyono. (2014). Metode Penelitian Pendidikan Pendekatan Kuantitatif, 